\title{
Effect of combination between bioagents and antioxidants on management of tomato powdery mildew
}

\author{
Abada K. A., M. A. Ahmed \\ Plant Pathol, Dept., Fac. Agric., Cairo Univ., Giza, Egypt \\ Email address: \\ dr_khairy_abada@yahoo.com (Abada K. A.)
}

To cite this article:

Abada K. A., M. A. Ahmed. Effect of Combination between Bioagents and Antioxidants on Management of Tomato Powdery Mildew. American Journal of Life Sciences. Special Issue: Role of Combination Between Bioagents and Solarization on Management of Crownand Stem-Rot of Egyptian Clover. Vol. 2, No. 6-2, 2014, pp. 26-32. doi: 10.11648/j.ajls.s.2014020602.14

\begin{abstract}
Isolation of microorganisms occurring on the phyllopane of tomato leaves yielded many Basillus and Trichoderma strains. The isolated Bacillus spp. were purified and identified as B. chitinosporus, B. megaterium, B. pumilus, B. subtilis and B. thuringiensis and the isolated Trichoderma spp. were, T. album, T. hamatum, T. koningii, T. harzianum and T.veredi. All the tested Bacillus and Trichoderma strains caused significant inhibition to the germinated conidia of Leveillula taurica (imperfect stage $=$ Oidiopsis taurica) the causal of tomato powdery mildew compared with control treatment. In addition, B. thuringiensis B. subtilis and B. chitinosporus were the most efficient bacteria in this regard and $T$. harzianum and T. veredi were the most efficient fungi. The inducer resistance chemicals (IRCs) bion, chitosan, humic acid, salicylic acid and zinc sulphate resulted in significant reduction to the germinated conidia of the causal fungus compared with control treatment. This reduction was gradually increased by increasing the tested concentration. In plastic house experiments, spraying tomato plants with the tested bioagents $B$. thuringiensis and T. harzianum and the IRC salicylic acid resulted in significant reduction to powdery mildew severity during 2012/2013 and 2013/ 2014 growing seasons. Spraying of the bioagents B.thuringiensis and T. harzianum and the IRC salicylic acid, each alone or in different combinations, resulted in significant reduction to the severity of the disease with significant increase to the produced fruit yield. Furthermore, spraying any of these compounds alone was of less effect in this regard compared with spraying their combinations. However, the fungicide Sumi- 8 was the superior in this regard, being $3.7 \%$ disease severity and fruit yield $16.2 \mathrm{~kg}$. / plant followed by the mixture of the three treatments, being $4.6 \%$ disease severity and fruit yield $13.7 \mathrm{~kg}$. / plant. The three oxidative-reductive enzymes, i.e. PAL, PO and PPO were greatly increased in the leaves of all sprayed treatments compared with control treatment. In addition, plants sprayed with salicylic acid recorded the highest activity of the three enzymes followed by that sprayed with $B$. thuringiensis then $T$. harzianum. Meanwhile, untreated leaves (control) recorded the lowest activity followed by that sprayed with Sumi-8.
\end{abstract}

Keywords: Bioagents, Inducer Resistance Chemicals, Powdery Mildew and Tomato

\section{Introduction}

Tomato (Solanum lycopersicum L.) is one of the most famous Solanecious crops either for local consumption and exportation. It is liable to infection by many fungal bacterial and viral diseases (Hannah et al., 2001and Jones et al., 2014). However, powdery mildew caused by Leveillula taurica (Lev.) Arn. (imperfect stage = Oidiopsis taurica), is one of the most damaging diseases that affect plastic houses tomatoes all over the world(Jones et al.,2014). Tomato powdery mildew is a common fungal disease affecting tomato plants. This type of mildew is caused by many types of fungi that do not require high humidity to get established, and prosper under mild conditions. These qualities make them more prevalent than many other plant diseases. Researches shown a direct correlation between the percentage of powdery mildew infection of the leaves and yield loss, where one percent mildew infection on the leaves would result in a one percent yield loss or more. An early, heavy infection with mildew had about $50 \%$ loss of production compared to a later, lighter infection (Cerkauskas et al., 2011 and Karkanis, et al., 2012). Plastic house tomato growers need to follow an intensive disease prevention plan because it is very important that powdery mildew never gets out of hand. 
Once tomato leaves are infected with powdery mildew it is difficult to control; if left unchecked the crop can be entirely destroyed. There are no powdery mildew resistant tomato varieties currently available (Hannah, et al., 2001 and Jones et al., 2014). Tomato powdery mildew is different in several ways from the mildews that infect other hosts. Tomato powdery mildew grows unseen, within the leaf tissue for a latency period of up to 21 days. Unlike tomato and cucumber powdery mildew is easily seen on the top side of the leaves. Disease monitoring, early detection and prevention of tomato powdery mildew is critical. In addition, tomato plants can become defoliated and do not recover as quickly as other greenhouse crops when infected with powdery mildew (Jones et al., 2014). Tomato powdery mildew does not infect the fruit or stems but can quickly destroy unprotected leaves and eventually the entire tomato crop. The fungus can cause disease in a wide range of temperature and relative humidity. However, optimal conditions for infection and disease development occur when the temperature is between 60 and $80^{\circ} \mathrm{F}$ with humidity greater than $85 \%$. Under favorable conditions, the fungus reproduces rapidly and spores can germinate and infect a plant in less than 48 hours. Wind-disseminated spores cause secondary infections, which help spread the disease. The disease is most severe at any time throughout the season if environmental conditions are favorable and severe infections early in the season can result in heavy yield losses (Jones et al., 2014).

The increasing of the severity of tomato powdery mildew on greenhouse-grown or field-grown plants under warm, humid conditions will require the development and evaluation of control tactics. In general, commercial fields receiving fungicides have had reduced incidence and severity compared to unsprayed bioproducer growers, which the disease is of concern to growers in IPM programs. Because of the disease severity has been greater the development of control tactics rather than fungicides for use is particularly important.

This work aimed to management tomato powdery mildew with some bacterial and fungal bioagents and inducer resistance chemicals.

\section{Materials and Methods}

\subsection{Isolation of the Antagonistic Bioagents}

Microorganisms naturally occurring on tomato leaf surface were isolated from the phylloplane of healthy plants, collected from Qaha, Kalubia governorate. Serial dilution plate technique was used to isolate native bacteria on nutrient agar medium and fungi on PDA medium (Oedjijono and Dragar, 1993).

Trichoderma spp. were selected from the isolated fungi then purified and identified depending on their morphological features and the description of Domsch et al. (1980) and Bissctt (1991).

Also, Bacillus spp. were selected from the isolated bacteria then purified and identified depending on the de11scription of Parry et al. (1983) and Holt and Krieg (1984). The identification was confirmed by the BiologSystem technique (Biological control of faba bean chocolate spot disease project, Plant Pathol. Res. Instit., A.R.C., Giza, Egypt).

\subsection{Effect on the Conidial Germination}

Tomato leaves naturally infected by the disease were collected from a plastic houses located at Qaha county, Kalubia governorate to tested the effect of some bioagents and IRCs on conidial germination of Leveillula taurica. Powdery mildew spores from the abaxial side of tomato leaves were collected.

- The tested bacterial isolates, i. e. Bacillus chitinosporus, B. megaterium, B. pumilus, B. subtilis, B.thuringiensis were grown on nutrient broth (NB) medium at $28 \pm 1{ }^{0} \mathrm{C}$ for $48 \mathrm{~h}$. The bacterial suspension was adjusted to contain $1 \times 10^{2}, 1 \times 10^{3}$, $1 \times 10^{4}, 1 \times 10^{5}$ and $1 \times 10^{6} \mathrm{cfu} / \mathrm{ml}$.

- Trichoderma spp., i.e. T. album, T. hamatum, T. koningii, T. harzianum and T.veredi were grown on PDA medium for 7 days. $20 \mathrm{ml}$. of sterile water was added to each Petri-dish and growth (spores and mycelium) was gently crushed by sterilized camel brush and collected in sterile $500 \mathrm{ml}$ conical glass. The collected growth was filter through 3 layer of cheesecloth and the filtrate was adjusted to contain $1 \times 10^{2}, 1 \times 10^{3}, 1 \times 10^{4}, 1 \times 10^{5}$ and $1 \times 10^{6}$ conidia using a haemocytometer.

- The inducer resistance chemicals (RICs), i.e. bion, chitosan, humic acid salicylic acid and zinc sulphate were prepared at $0.0,20,40,60,80$ and $100 \mathrm{mM}$ depending on their molecular weight.

Freshly collected conidia by sterilized camel brush from the infected leaves were put in each concentration of the tested bioagents and IRCs. One m1.of conidial suspension was placed on two sterilized slide, borne on two glass rods in a sterilized Petri -dish containing a piece of wetted cotton by sterilized distilled water to provide high relative humidity. The same was made for a spore suspension put in distilled sterilized water only as control treatment. Five dishes were used for each treatment .Preparations were incubated in an incubator at $28 \pm 1{ }^{\circ} \mathrm{C}$ for $48 \mathrm{~h}$. One drop from lacto-phenol cotton blue stain was added at the time of slide examination to fix and killing the germinated conidia. Percentage of conidial germination was counted in a total of 100 conidia in each replicate. The germinated conidia were counted and percentages mean of germination was calculated and recorded for each treatment.

\subsection{Effect of the Tested Bioagents and IRCs on Severity of the Disease and the Produced Fruit Yield under Plastic House Conditions}

Plastic house experiments were carried out at Qaka, Kalubia governorate, where symptoms of severe infection 
by the disease occurs annually beginning from end of February to beginning of March. The plastic house $(7 \times 90 \mathrm{~m})$ was divided into ridges of one $\mathrm{m}$ wide. Tomato transplants (Novo cv.) of 35 days old grown in Foam trays were transplanted at $50 \mathrm{~cm}$ apart on the two sides of the ridges on crow-leg at mid of November of 2012 and 20013 .The prepared bioagent cultures of B.thuringiensis $\left(1 \times 10^{4} \mathrm{cfu} / \mathrm{ml}\right.$. water), T. harzianum $\left(1 \times 10^{6}\right.$ conidia / $\mathrm{ml}$. water $)$ and the IRC salicylic acid at $100 \mathrm{mM}$ ( amended with calculated aliquots of an adhesive surfactant super-film at $50 \mathrm{ml} / 100 \mathrm{~L}$. water) were sprayed, each alone or in combinations, onto the upper and the lower leaf surfaces of the plants before appearing the visual symptoms of the disease ( end of February). Also, the fungicide Sumi-8 (diniconazole) was sprayed as a recommended fungicide for management of tomato powdery mildew at the rate of $35 \mathrm{ml} / 100 \mathrm{~L}$ water. Plants sprayed with tap water only (likely amended with the adhesive surfactant) were served as control treatment. Four replicates of 14 plants for each treatment were used, which the criteria were assessed on 12 plants and two plant were left among treatments. Spraying was repeated three times each 10 days.

All agricultural practices, i.e. irrigation, weeds and pests control as well as fertilization were applied according to the standard recommendations of Ministry of Agriculture and Land Reclamation.

Disease severity was assessed just before the following spray as mentioned under disease assessment and the average was recorded. Also, the produced fruit was weighed each harvest and the average was recorded.

\subsection{Estimation of Oxidative-Reductive Enzymes}

The activity of phenylalanine ammonia lyase (PAL , peroxidase (PO) and polyphenol oxidase (PPO) was measured in tomato leaves free from the pathogen and sprayed with the tested two bioagents (B.thuringiensis and T. harzianum ), the IRC salicylic acid and the fungicide Sumi-8. Samples were taken after two weeks from the treatment to the plants by the different treatments for enzymes assays. One gram of tomato leaf sample was homogenized with $2 \mathrm{ml}$ of $0.1 \mathrm{M}$ sodium phosphate buffer (pH 7.0) in ice bath for enzyme assays. The homogenates were then centrifuged at $10,000 \mathrm{~g}$ for $10 \mathrm{~min}$. Supernatants were used to analyze the defense-related enzymes ,PAL, PO, and PPO activities.

\subsubsection{Estimation of PAL Activity}

The activity of phenylalanine ammonia lyase (PAL) was determined according to the method of Burrell and Rees (1974). The reaction mixture contained $0.03 \mathrm{M} \mathrm{L-}$ phenylalanine and $0.2 \mathrm{ml}$ enzyme extract in a total $2.5 \mathrm{ml}$ of sodium borate buffer ( $\mathrm{pH} 8.8)$. This reaction mixture was kept in a water bath at $37{ }^{\circ} \mathrm{C}$ for $1 \mathrm{~h}$, and $0.5 \mathrm{ml}$ of $1 \mathrm{M}$ (trichloroacetic acid) TCA was added. The amount of transcinnamic acid formed from L-phenylalanine was measured spectrophotometrically at $290 \mathrm{~nm}$. Enzyme activity was expressed as microgram of trans-cinnamic acid $\mathrm{h}^{-1} \mathrm{mg}^{-1}$ protein.

\subsubsection{Estimation of PPO Activity}

The activity of polyphenol oxidase (PPO) was determined according to the method proposed by Mayer et al.(1965). The reaction mixture was containing $200 \mu \mathrm{l}$ enzyme extract and $1.5 \mathrm{ml}$ of $0.01 \mathrm{M}$ catechol. Activity was expressed as changes in absorbance at 495 $\mathrm{nm} \cdot \mathrm{min}^{-1} \mathrm{mg}^{-1}$ protein.

\subsubsection{Estimation of $P O$ Activity}

To estimate peroxidase activity (PO), $50 \mu \mathrm{l}$ of enzyme extract was added to $2.85 \mathrm{ml}$ of $0.1 \mathrm{M}$ phosphate buffer $(\mathrm{pH}$ 7.0) and mixed with $0.05 \mathrm{ml}$ of $20 \mathrm{mM}$ guaiacol reagent (Fu and Huang, 2001). The reaction was started by the addition of $0.02 \mathrm{ml}$ of $40 \mathrm{mM}$ hydrogen peroxide to the mixture. Rate of increase in absorbance at $470 \mathrm{~nm}$ was measured over $1 \mathrm{~min}$. One unit of enzyme activity was defined by the change in absorbance of 0.01 for $1 \mathrm{~g}$ fresh weight per minute.

\subsection{Disease Assessment}

Plants were examined periodically and disease measures were determined using the modified scale (0-5) adopted with Horsfall and Barret (1945), where $0=$ No symptoms appear; $1=0.1$ to $5 \%$ of leaflet area covered by the infection; $2=$ more than 5 to $10 \%$ of leaflet area covered by the infection; $2=$ more than 10 to $25 \%$ of leaflet area covered by the infection; $4=$ more than 25 to $50 \%$ of leaflet area covered by the infection; $5=$ more than $75 \%$ of the plant growth covered by the infection and the most leaves of the plants defoliated.

The grown plants were periodically examined for disease symptoms to estimate the severity of the disease and the final averages were recorded using the following formula:

$$
\text { Disease sevenity } \%=\frac{\sum(\mathrm{nxv})}{5 \mathrm{~N}} \times 100
$$

Where: $n=$ Number of infected leaves in each category.

$\mathrm{v}=$ Numerical values of each category.

$\mathrm{N}=$ Total number of the infected leaves.

\subsection{Statistical Analysis}

Data were statistically analyzed using the standard procedures for compete randomized block and split designs as mentioned by Snedecor and Cochran (1967). The averages were compared at 5\% level using least significant differences (L.S.D) according to Fisher (1948).

\section{Results}

\subsection{Effect of the Tested Bioagents on Conidial Germination}

\subsubsection{Effect of the Tested Bacterial bioagents}

Data presented in Table (1) indicate that all the tested bioagents resulted in significant reduction to the 
germinated conidia of L.taurica compared with control treatment. This reduction was gradually increased by increasing the tested concentration. In addition, B.thuringiensis was the most efficient one in this regard, being $31.2 \%$ conidial germination followed by $B$. subtilis, being $34.6 \%$ then $B$. chitinosporus, being $34.7 \%$ conidial germination. Meanwhile, $B$. megaterium was the lowest efficient one being, $38.8 \%$ conidial germination followed by $B$ pumilus., being $37.6 \%$ conidial germination. Control treatment recorded $95.6 \%$ conidial germination.

\subsubsection{Effect of the Tested Fungal Bioagents}

Table (1) indicates that all the tested fungal bioagents resulted in significant reduction to the germinated conidia of L.taurica compared with control treatment. This reduction was gradually increased by increasing the tested concentration. In addition, T.harzianum was the most efficient one in this regard, being $54.2 \%$ conidial germination followed by T.veredi, being $55.9 \%$ conidial germination. Meanwhile, T. album was the lowest efficient one being, $61.2 \%$ conidial germination . Both T. hamatum and $T$. koningii resulted in, to some what, similar effect being 60.4 and $60.0 \%$ conidial germination, respectively. Control treatment recorded $95.6 \%$ conidial germination.

Table 1. Effect of the tested bioagents on conidial germination of L.taurica, 48 hours after incubation at $28 \pm 1{ }^{\circ} \mathrm{C}$.

\begin{tabular}{lccccccc}
\hline \multirow{2}{*}{ Bioagents } & \multicolumn{8}{c}{$\begin{array}{l}\text { Average percentage of conidial } \\
\text { germination* at con. of 1x10 }\end{array}$} & & Mean \\
& $\mathbf{0 . 0}$ & $\mathbf{2}$ & $\mathbf{3}$ & $\mathbf{4}$ & $\mathbf{5}$ & $\mathbf{6}$ & \\
\hline Bacillus spp. & & & & & & & \\
B.chitinosporus & 95.6 & 69.8 & 43.0 & 19.0 & 0.0 & 0.0 & 34.7 \\
B. megaterium & 95.6 & 71.2 & 45.4 & 20.4 & 0.0 & 0.0 & 38.8 \\
B. pumilus & 95.6 & 69.0 & 42.2 & 18.6 & 0.0 & 0.0 & 37.6 \\
B.subtilis & 95.6 & 65.0 & 36.8 & 10.0 & 0.0 & 0.0 & 34.6 \\
B.thuringiensis & 95.6 & 61.2 & 30.6 & 0.0 & 0.0 & 0.0 & 31.2 \\
Trichoderma spp. & & & & & & & \\
T. album & 95.6 & 91.6 & 81.6 & 53.2 & 32.0 & 13.0 & 61.2 \\
T..hamatum & 95.6 & 91.0 & 80.8 & 52.4 & 31.2 & 11.6 & 60.4 \\
T.koningii & 95.6 & 90.8 & 80.0 & 52.0 & 30.8 & 11.0 & 60.0 \\
T.harzianum & 95.6 & 86.4 & 78.0 & 46.8 & 18.6 & 0.0 & 54.2 \\
T.veredi & 95.6 & 88.6 & 80.6 & 48.6 & 21.8 & 0.0 & 55.9 \\
Mean & 95.6 & 68.5 & 59.9 & 32.1 & 13.4 & 3.6 & ----- \\
\hline
\end{tabular}

* Initial germination percentage was $2.0 \%$

** $\mathrm{x}=$ Numerical number of concentration.

L.S.D. at $5 \%$ for: Bioagents $(B)=2.3$, Concentrations $(C)=2.9$ and $\mathrm{I} x \mathrm{C}=$ 3.3 .

\subsection{Effect of the Tested IRCs on Conidial Germination}

Results tabulated in Table (2) reveal that all the tested IRCs resulted in significant reduction to the germinated conidia of L. taurica compared with the control treatment. This reduction was gradually increased by increasing the tested concentration. In this regard, salicylic acid was the most efficient one in this regard, being $41.6 \%$ conidial germination followed by chitosan, being $42.5 \%$ conidial germination. Meanwhile, zinc sulphate was the lowest effective one, being $45.5 \%$ conidial germination followed by being $44.5 \%$ conidial germination. Control treatment recorded $94.2 \%$ conidial germination.

Table 2. Effect of some inducer resistance chemicals (IRCs) on conidial germination of L . taurica, 48 hour after incubation at $28 \pm 1^{\circ} \mathrm{C}$.

\begin{tabular}{|c|c|c|c|c|c|c|c|}
\hline \multirow{2}{*}{$\begin{array}{l}\text { Inducer } \\
\text { resistance } \\
\text { chemical }\end{array}$} & \multicolumn{6}{|c|}{$\begin{array}{l}\text { Average percentage of conidial } \\
\text { germination at con. }(\mathrm{mM}) *\end{array}$} & \multirow[t]{2}{*}{ Mean } \\
\hline & 0.0 & 20 & 40 & 60 & 80 & 100 & \\
\hline Bion & 94.2 & 89.8 & 63.0 & 49.0 & 30.0 & 10.0 & 34.7 \\
\hline Chitosan & 94.2 & 91.2 & 65.4 & 50.4 & 33.2 & 13.4 & 38.8 \\
\hline Humic acid & 94.2 & 89.0 & 62.2 & 48.6 & 30.0 & 10.8 & 37.6 \\
\hline Salicylic acid & 94.2 & 83.0 & 56.8 & 28.0 & 0.0 & 0.0 & 34.6 \\
\hline Zinc sulphate & 94.2 & 87.2 & 60.6 & 43.0 & 22.0 & 7.0 & 31.2 \\
\hline Mean & 94.2 & 68.5 & 59.9 & 32.1 & 13.4 & 3.6 & ----- \\
\hline
\end{tabular}

* Initial germination percentage was $1.8 \%$.

L.S.D. at $5 \%$ for : Inducer resistance chemicals $(\mathrm{I})=2.7$, Concentrations (C) $=2.5$ and $\mathrm{I} \times \mathrm{C}=3.2$.

\subsection{Effect of the Two Bioagents and the IRC Salicylic Acid on Disease Severity and Fruit Yield}

Results (3) show that spraying tomato plants with the tested two bioagents, i.e.B.thuringiensis and T.harzianum and the IRC salicylic acid, each alone or in different combinations, resulted in significant reduction to the severity of the disease compared with control treatment. The highest reduction was obtained by the combination among the three treatments (the two bioagents and the IRC), being $4.6 \%$ disease severity nearby the effect of the systemic fungicide Sumi-8, being $3.7 \%$ disease severity. Control treatment recorded $49.2 \%$ disease severity. Intermediate reduction to the disease severity was occurred when the plants sprayed with the combination between any of the two combinations of these treatments. Meanwhile, low efficiency was noticed when any of B.thuringiensis and T.harzianum and the IRC salicylic acid was sprayed alone, being 11.3, 13.0 and $10.6 \%$, respectively.

Data presented in Table (3) indicate that tomato plants sprayed with any of the two tested bioagents and the IRC, each alone or in different combinations, resulted in significant increment to the produced fruit yield compared with control treatment. Also, spraying the fungicide Sumi-8 was the superior treatment (16.2 kg/plant) and spraying any of the two bioagents and the IRC alone was of low efficiency in this regard, being $8.8,8.3$ and $9.6 \mathrm{~kg} / \mathrm{plant}$ than spraying their different combinations .

No significant effect on the severity of the disease and the produced fruit yield due to the effect of the growing season was found. 
Table 3. Effect of spraying tomato plants with the two bioagents B.thuringiensis and T.harzianum and the IRC salicylic acid, each alone or in different combinations, on the severity of natural infection by powdery mildew and the produced fruit yield, plastic house experiments at Qaka, Kalubia governorate during 2012/2013 and 2013/2014 growing seasons.

\begin{tabular}{|c|c|c|c|c|c|c|}
\hline \multirow{2}{*}{ Treatments * } & \multicolumn{2}{|c|}{$\%$ Disease severity during } & \multirow{2}{*}{ Mean } & \multicolumn{2}{|c|}{ Average fruit yield (kg.) / plant during } & \multirow{2}{*}{ Mean } \\
\hline & $2012 / 2013$ & $2013 / 2014$ & & $2012 / 2013$ & $2013 / 2014$ & \\
\hline B.thuringiensis(BT) & 11.0 & 11.6 & 11.3 & 9.0 & 8.6 & 8.8 \\
\hline Salicylic acid (SA) & 10.5 & 10.6 & 10.6 & 9.8 & 9.4 & 9.6 \\
\hline $\mathrm{BT}+\mathrm{TH}$ & 8.6 & 9.0 & 8.6 & 11.6 & 11.0 & 11.3 \\
\hline $\mathrm{BT}+\mathrm{SA}$ & 7.8 & 8.0 & 7.9 & 12.3 & 12.0 & 12.2 \\
\hline $\mathrm{TH}+\mathrm{SA}$ & 8.0 & 8.2 & 8.1 & 12.0 & 12.6 & 12.3 \\
\hline $\mathrm{BT}+\mathrm{TH}+\mathrm{SA}$ & 4.4 & 4.7 & 4.6 & 14.2 & 13.4 & 13.7 \\
\hline Sumi-8 & 3.6 & 3.8 & 3.7 & 16.4 & 16.0 & 16.2 \\
\hline Control & 48.3 & 50.1 & 49.2 & 5.3 & 5.1 & 5.2 \\
\hline Mean & 12.8 & 13.2 & ----- & 11.0 & 10.7 & ----- \\
\hline
\end{tabular}

*The plants received 3 sprays from each compound or their combination.

L.S.D. at $5 \%$ for:

Treatments $(\mathrm{T})=$

Season $(\mathrm{S})=$

$\mathrm{T} \times \mathrm{S}=$

$\begin{array}{ll}2.4 & 3.2 \\ \text { n.s. } & \text { n.s. } \\ 3.6 & 3.8\end{array}$

\subsection{Changes in the Activity of Oxidative-Reductive Enzymes}

Table (4) shows the changes in the activity of oxidativereductive enzymes, i.e. phenylalanineammonia lyase (PAL), peroxidase $(\mathrm{PO})$ and polyphenol oxidase (PPO) due to spraying tomato plants with two bioagents, i.e. B. thuringienses and T.harzianum as well as the IRC salicylic acid and the fungicide Sumi- 8 compared with the untreated control.

Data reveal that, in general, the three enzymes, i.e. PAL, PO and PPO were greatly increased in the leaves of all sprayed treatments compared with control treatment. In addition, plants sprayed with salicylic acid recorded the highest activity of the three enzymes followed by that sprayed with B.thuringiensis then T.harzianum, being 1.487, 1.265 and 1.334, respectively. Meanwhile, untreated leaves (control) recorded the lowest activity followed by that sprayed with Sumi-8, being 0.814 and 1.051, respectively.

Table 4. Effect of spraying tomato plants with two bioagents and the IRC salicylic acid in comparison with the fungicide Sumi-8 on the activity of oxidative reductive enzymes.

\begin{tabular}{lllll}
\hline Treatments & \multicolumn{3}{c}{ Activity of enzymes * } & Total \\
\hline B. thuringiensis & 0.421 & 0.402 & 0.542 & 1.365 \\
T.harzianum & 0.400 & 0.413 & 0.521 & 1.334 \\
Salicylic acid & 0.482 & 0.442 & 0.563 & 1.487 \\
Sumi-8 & 0.350 & 0.311 & 0.390 & 1.051 \\
Control & 0.220 & 0.244 & 0.350 & 0.814 \\
Total & 0.190 & 0.182 & 0.238 & ----- \\
\hline
\end{tabular}

* Expressed as absorption after $30 \mathrm{sec}$. at appropriate wave length and the activity of PAL, PO and PPO at zero time were 0.220, 0.244 and 0.350, respectively.

\section{Discussion}

The production of healthy and safe food free from toxic substances is the desire of the consumer, especially that consume freshly like tomato. Therefore, to avoid the use of hazard chemicals against diseases, certain protective or curative procedures could be conducted using different non-chemical methods to control such diseases. In this regard, bioagents and inducer resistance chemicals (IRCs) were evaluated for management tomato powdery mildew. However, in most cases, using such untraditional management methods did not give adequate results when used alone. In this respect, the use of these methods is preverbal to use as a mixture.

The tested bioagents and the IRCs caused significant reduction to conidial germination of Leveillula taurica (imperfect stage $=$ Oidiopsistaurica) the causal of tomato powdery mildew compared with control treatment. This reduction was gradually increased by increasing the tested concentration. In addition, spraying tomato plants with the bioagents B.thuringiensis and T.harzianum and the IRC salicylic acid, each alone or in different combinations, resulted in significant reduction to the severity of the disease with significant increase to the produced fruit yield. Furthermore, spraying any of these compounds alone were less efficient in this regard compared with spraying their combinations. However, the fungicide Sumi- 8 was the superior in this regard followed by the mixture of the two bioagents and the IRC salicylic acid .

Chemical control is highly recommended because powdery mildew is an aggressive and destructive disease and satisfactory control without the use of fungicides is unlikely. The role of fungicides in reducing the disease is well known (Mc Grath, 2001) .But due to the great hazard on the human health due to the residue of agrochemicals in the consume food, fungicides become unlikely to use. 
Therefore, great efforts by agro-scientists are spend to search about alternative safely methods to management plant pests. In this respect, this work aimed to evaluate spraying tomato plants with the two bioagents $B$. thuringiensis and T. harzianum and the IRC salicylic acid, each alone or in different combinations, on management of tomato powdery mildew.

It has been found that, in general, the three enzymes PAL, PO and PPO were greatly increased in the leaves of all treatments by $B$. thuringiensis, T. harzianum, salicylic acidand the fungicide Sumi- 8 compared with control treatment. In addition, plants sprayed with salicylic acid recorded the highest activity of the three enzymes followed by that treated with $B$. thuringiensis and $T$. harzianum. It has been found that the reduction in disease severity was attributed to the increased levels of PAL, PO and PPO enzymes.

Farkas and Kiraly (1962) and Morkunas et al.(2007) reported that peroxidase enzyme oxidizes the phenolics to more fungal toxic compounds such as quinines, which inhibit both spore germination and fungal growth. Also, peroxidase was found to be participate in the synthesis of lignin. Moreover, Farkas and Kiraly (1962) and Melo et al. (2007) declared that the participation of an endogenous supply of phenolic compound in the plant disease resistance is dependent upon active phenol oxidase system.

Protection of plants from plant pathogens by induction of systemic resistance is a new approach and is of much less harmful to the environment and plant products as compared to deadly agrochemicals applied to control plant diseases. Yan et al., (2003) reported that induced systemic resistance was observed in tomato against late blight, caused by Phytophthora infestans (Mont.) with B. pumilus strain SE34n that was incorporated into the potting medium. Also, Bacillus megaterium strain 4 was found to be effective to control Fusarium wilt of tomato (Terhardt, 1998); B. thuringiensis was used to induce systemic resistance in mung bean plants against root colonizing phytopathogenic fungi ( Sheikh et al.,2006); $B$. thuringiensis strains capable of inducing systemic response to Fusarium wilt of tomato (Akramet al .,2013).

The obtained results revealed a significant reduction in the disease severity of the natural infection by powdery mildew of tomato plants sprayed with the two bioagents and the IRC salicylic acid compared with control treatment.

Pathogenicity-related proteins are usually quantified to assess the activation of defense system of plants. Plants treated with the two bioagents, the IRC salicylic acid and the fungicide Sumi-8 compared with control treatment showed, also, an increase in PAL, PO and PPO activity. It is well known that PPO is a copper containing enzyme, which is responsible for oxidization of phenolics to highly toxic quinines. This enzyme is also involved in terminal oxidation of diseased plant tissue, and this role of this enzyme is attributed in disease resistance (Kosuge, 1996). On the other hand, PAL is the main enzyme in phenyl propanoid pathway and flavonoid pathway (Scott et al.,
1995) and peroxidase enzyme is related with more than one function in plants.

Larcke (1981) found that unlike elicitors of phytoalexines accumulations, which are elicited at the site of application may be responsible for localized protection and induces systemic acquired resistance that sensitizes the plant response rapidly after infection. These responses induced phyto-alexines accumulation and lignifications and induce enhance activities of chitinase and $\beta$-glucanase (Dean and Kuc, 1985 and Metranx and Boller, 1986). Doubrava et al. (1988) mentioned that induced acquired resistance is persistent and generally is pathogen nonspecific. Moreover, Kessmann et al. (1994) mentioned that the mechanism of systemic acquired resistance is apparently multifaceted, likely resulting in stable broad spectrum disease control and they could be used preventatively to bolster general plant health, resulting in long lasting protection. Iriti and Faoro (2003) reported that bion was used to induce resistance in bean against rust caused by Uromyces appendiculatus. Histochemical and cyto-chemical investigations showed that benzothiadiazole $(\mathrm{BTH})$ causes hydrogen peroxide $\left(\mathrm{H}_{2} \mathrm{O}_{2}\right)$ accumulation in the treated tissues. $\mathrm{H}_{2} \mathrm{O}_{2}$ deposits were localized in situ for the first time in the apoplast of the leaf epidermis. No cell death was detected at BTH concentrations below the phytotoxicity threshold, suggesting that acquired resistance against bean rust is mainly related to the enhanced activity of anionic peroxidases, promoted by $\mathrm{H}_{2} \mathrm{O}_{2}$ accumulation, thereby leading to cell wall strengthening. This hypothesis is also supported by the long induction phase required to establish complete resistance.

\section{References}

[1] Akram, W.; Mahboob, A and Javel A.A.(2013). Bacillus thuringiensis strain 199 can induce systemic resistance in tomato against Fusarium wilt. Europ.J. of Mirobiol. and Immunol., 275-280.

[2] Bissett J. (1991). A revision of the genus Trichoderma. W: Infragenic classification. Can. J. Bot., 69:2357-2317.

[3] Burrell M.M. and Rees T.A. (1974). Metabolism of phenylalanine and tyrosine in rice leaves infected by Pyricularia oryzae. Physiol Plant Pathol., 4: 497-508.

[4] Cerkauskas, R. F.; Ferguson G. and Banik M. (2011). Powdery mildew (Leveillula taurica) on greenhouse and field peppers in Ontario - host range, cultivar response and disease management strategies. Canad. J. of Plant Pathol., 33(4): 485-498.

[5] Dean R.A. and Kuc J.(1985). Induced systemic protection in plants .Trends Biotechnol., 3: 125-128.

[6] Domsch K.H.; Gams W. and Anderson T.H. (1980). Compendium of Soil Fungi. Vol. 1 and 2, Academic press. London.

[7] Doubrava N.; Dean R . And Kuc J. (1988). Induction of systemic resistance to anthracnose caused by Colltetrichum lagenarum from spinach and hubar leaves. Physiol. Mol. Plant Pathol., 33: 60-70. 
[8] Farkas L. and Kiraly L. (1967). Role of phenolic compounds in the physiology of plant disease and disease resistance. Phytopathol.Z., 40: 106-150.

[9] Fisher R.A. (1948). Statistical Methods $6^{\text {th }}$ ed. Iowa State Univ. Press, Ames, Iowa, USA.

[10] Fu J. and Huang B. (2001).Involvement of antioxidants and lipid peroxidation in the adaptation of two cool-season grasses to localized drought stress. Environ Exp. Bot., 45(2): 105-114

[11] Hannah J.; John M.W. and Jans,Sarah G. (2001).The tomato powdery mildew fungus Oidiumneo lycopersici. Molecul. Plant Pathol., 2(6): 303-309.

[12] Holt J.G. and Krieg N.R.(1984). Bergey's Manual of Systematic Bacteriology. Williams \& Wilkins, Baltimore, USA.

[13] Horsfall H.A.J. and Barratt R.W.(1945).An improved gardening system for measuring plant diseases. Phytopathology, 35:655.

[14] Hulme A.C. (1970).The biochemistry of fruits and their products.A.R.C. Food Res.Instit., England Cad.Press,London and New York.620 pp.

[15] Iriti M. and Faoro, F.(2003). Benzothiadiazole (BTH): Induces cell-death independent resistance in Phaseolus vulgaris against Uromyces appendiculatus. J. of Phytopathol, 151(3): 171-180.

[16] Jones B.J.; Zitter T. A., Momol T.M. and Miller, Sally A. (2014). Compendium of Tomato Diseases and Pests. Second Edition. The American Phytopathological Society, 179 pp.

[17] Karkanis A.; Bilalis D.; Efthimiadou A. and Katsenios N. (2012). Effects of field bindweed (Convolvulus arvensis L.) and powdery mildew [Leveillula taurica (Lev.) Arn.] on pepper growth and yield. Hort. Sci., 39(3): 135-138

[18] Kessmann H. ; Sataub T.; Hofmann C.; Meatzke T. and Herzog J.(1994). Induction of systemic acquired disease resistance in plants by chemicals. Ann. Rev. Phytopathol., 32: 439-459.

[19] Kosuge T. (1996). The role of phenolics in host response to infection to infection. Ann. Rev. Phytopathol., 7:195-222.

[20] Larcke P. (1981). Alternative chemical agents for controlling plant diseases. Phil. Trans. Res. Soc., 2: 83- 101.

[21] Mayer A.M.; Harel E. and Shaul R. B. (1965). Assay of catechol oxidase a critical comparison of methods. Phytochem., 5:783-789.

[22] McGrath, Margret, T. (2001).Fungicide resistance in cucurbit powdery mildew. Plant Dis., 85(3): 236- 250.

[23] Melo G.A.; Shimizu M. M. and Mazzafera P. (2006). Polyphenoloxidase activity in coffee leaves and its role in resistance against the coffee leaf miner and coffee leaf rust. Phytochemistry., 67: 277-285.

[24] Metranx J. D. and Boller T. (1986). Local and systemic induction of chitinase in cucumber plants in response to fungal, bacterial and viral infections. Physiol. Mol. Pathol., 28: 161-169.

[25] Morkunas I. and Gemerek J. (2007). The possible involvement of peroxidase in defense of yellow lupine embryo axes against Fusarium oxysporum. J. Plant Physiol., 164: 497-506.

[26] Oedjijono, M. A. L. and Dragar, C. (1993). Isolation of bacteria antagonistic to a range of plant pathogenic fungi. Soil Biol. Biochem., 25: 247-250.

[27] Parry, J.M.; Turnbull P.C.B. and Gibson J.R. (1983). A colour atlas of Bacillus species, Wolfe Medical Publications Ltd.

[28] Snedecor, G. W. and Cochran W.G. (1967).Statistical Methods. $6^{\text {th }}$ Ed. Iowa State Univ. Press, Ames, Iowa, USA.

[29] Scott-Carig J.S.; Kerby K.B.; Stein B.D. and Somerville S.C. (1995). Expression of an extracellular peroxidase that is induced in barley (Hordium vulgar) by powdery mildew pathogen (Erysiphe graminis f. sp. hordei) Physol. Mol. Plant Pathol., 47: 407-418.

[30] Sheikh L.I.; Dawar S.; Zaki M.J. and Ghaffar A. (2006). Efficacy of Bacillus thuringiensis and Rhizobium meliloti with nursery fertilizers in the control of root infecting fungi on mung bean and okra plants. Pak J Bot., 38:465-473.

[31] Terhardt J. (1998). Bee influssung mikrobieller Gemeinschaften der Rhizosphärenach Blattbehandlung von Pflanzen und biologische Kontrolle von Fusarium oxysporum f. sp. lycopersici und Meloidogyne incognita mitbakteriellen Anatgonisten. Ph.D. Thesis, Universität Bonn, Bonn, Germany.

[32] Yan Z.; Reddy M.S. and Kloepper J.W. (2003). Survival and colonization of rhizobacteria in a tomato transplant system. Can. J. Microbiol., 49(6):383-389. 